\title{
China's Legal Enforcement on Anti-Piracy in South China Sea
}

\author{
Yingying Deng \\ National Institute for South China Sea Studies \\ Rm 1801, Wanfu Building, No. 42 Bailong South Road, Haikou 570203, Hainan, China \\ Tel: 898-6522-0291_E-mail:luckydyy@hotmail.com
}

\begin{abstract}
The South China Sea is considered the most dangerous area for piracy in the world.

China has a strong economic interest in South China Sea and Strait of Malacaa maritime security. In recent year, China has taken effective measures in combating piracy in the South China Sea. In order to build the legislation and law-enforcement on anti-piracy, the author put forward some suggestion.
\end{abstract}

Keywords: Piracy, South China Sea, Legal enforcement

The South China Sea, encompassing an area from Singapore to the Strait of Taiwan of around 3,500,000 square kilometers, is bounded on the north by China, on the east of the Philippine islands, on the south of the Indo, and on the west by the Malay Peninsular and Vietnam. It contains more than 230 scattered islets, reefs, and shoals and are subdivided into four sub-archipelagos: The Spratly Islands, The Macclesfield Islands, The Paracel Islands and Pratas Islands. It is the world's most perplexing problems of maritime management and jurisdiction.

Linking the Indian Ocean with the South China Sea, Strait of Malacca is one of the world's most important sea passages. Straits of Malacca is about $900 \mathrm{~km}$ to $5.4 \mathrm{~km}$ wide, with an average depth of 25 meters to 27 meters. Today, shipping oil passing through the Straits of Malacca accounts for half of the world's oil shipping, a third of the world's shipping trade. The South China Sea is considered the most dangerous area for piracy in the world.

China has a strong economic interest in South China Sea and Strait of Malacaa maritime security. Its booming economy relies heavily on seaborne trade and energy imports. China has been a net oil importer since 1993. Now, $90 \%$ of China's trade and more than $80 \%$ of those energy imports pass through the South China Sea and Malacca Strait.

\section{Piracy}

Piracy in the South China Sea has a long history, dating back at least as far as the fourteen century. For no less than half of those 290 years (between 1520-1810) pirates dominated the seas around South China Sea. In recent years, piracy has gradually exhibited a more global nature, has been conducted in a more strictly organized manner and has become more violent.

Traditionally, piracy has been described as hostes Hunami generic- the enemy of the human race. In Ming dynasty, the Japanese businessmen often pirates in China's southeastern coastal harassment. They colluded with the Ming dynasty local tyrant profiteers. These bandits are called "Japanese Pirates" (Wo Kou). The Japanese pirates, can be mustered on over one hundred dispatched warships, several hours invasion, attacking the city ransacking stockade, murder and arson, raping, kidnapping and looting. Japanese pirates massive invasion of years, people's live and property along the southeast coast suffered incalculable damage.

China has no such word as "piracy" in the Chinese law, China use the term "robbery at sea" which can be deemed to be "piracy" in the sense of international regulations.

Piracy means unlawful acts as defined in article 101 of the 1982 United Nations Convention on the Law of the Sea (UNCLOS):

ARTICLE 101

Definition of Piracy consists of any of the following acts:

1) any illegal acts of violence or detention, or any act of depredation, committed for private ends by the crew or the passengers of a private ship or a private aircraft, and directed-

(a) on the high seas, against another ship or aircraft, or against persons or property of any State;

(b) against a ship, aircraft, persons or property in a place outside the jurisdiction of any State; 
2) any act of voluntary participation in the operation of a ship or of an aircraft with knowledge of facts making it a pirate ship or aircraft;

3) any act of inciting or of intentionally facilitating an act described in subparagraph (1) or (2).

The UNCLOS definition restricts acts of piracy to the "high seas" and "outside the jurisdiction of any state."

The IMO follows the 1982 United Nations Convention on the law of the Seas (UNCLOS), which in its article 101 declares piracy a criminal act. The IMB's definition differs from that of piracy that the UN has accepted. Piracy, as defined in the United Nations Convention on the law of the Seas (UNCLOS), includes only those acts of maritime predation occurring on the high seas and for private ends. The IMB has adopted a broader definition of piracy. Its definition is "An act of boarding or attempting to board any ship with the intent to commit theft or any other crime and with the intent or capability to use force in the furtherance of that act." With this definition, the IMB allows the inclusion of acts occurring within the territorial waters of states which meet the classical definition of piracy excepting the "high seas" criterion or, in cases of terrorism on the seas, the "private ends" criterion.

\section{Insert Table 1 Here}

\section{What Chinese Government has done in recent years}

In recent year, China has taken effective measures in combating piracy at sea, successfully investigated and settled five cases of piracy and armed robbery incidents that occurred in the South China Sea areas, apprehended and convicted criminals in a timely manner. The result is in a forceful suppression of and a heavy blow against piracy. (The 5 cases are: December 1998 hijacking of the Cheung Son, September 1998 hijacking of the Louisa, September 1998 hijacking of Ten Yu, March 1999 hijacking of Master of Ocean and February 2000 hijacking of Global Mars and March 1999 hijacking of Mary Master)

\subsection{Legal efforts to anti-piracy}

The Chinese government, as a contracting party to the UN Convention on the Law of the Sea and Convention for the Suppression of Unlawful Acts against the Safety of Maritime Navigation (China singed the LOS Convention in 1982 and ratified it in 1996, also ratified the two 1988 Rome legal documents against maritime terrorism), and relevant conventions of IMO, has been active and firm in combating piracy, and has exerted arduous efforts in this regard.

Criminal Law of the People's Republic, "Article 9 states": for the crimes defined in international treaties, concluded or acceded to by the People's Republic of China, Which are under the jurisdiction of the People's Republic of China within the framework of the treaty obligations, this Law shall apply. Therefore, China enjoy universal criminal jurisdiction on some international crime including piracy. In judicial practice, Chinese courts can use traditional criminal charges, such as murder, robbery, to punish pirates. In December 1999, the Intermediate People's Court of Shanwei (a coastal city in Guangdong Province) used Chinese criminal charges to sentence 13 people to death and gave 19 others sentences ranging from life imprisonment to short terms for being found guilty of hijacking the Hong Kong "Cheung Son" bulk carrier in 1998 and murdering 23 of its crew.

On $28^{\text {th }}$, December, 2000, Chinese Government promulgated and carried out an Extradition Law which provides powerful guarantees to the international jurisdictional cooperation on anti-terrorism. To international Criminals to extradition or prosecution, China's regulations on the handling of extradition cases concluded or acceded to all international treaties on specific crime, in particular the provisions of the State party "or extradition, or prosecute" obligations, the crime was deem to satisfy the conditions for extradition, but except for a reservation clause, on the other hand, if China decided not to extradite the international criminals having been accused or convicted of crimes, China will be in accordance with the relevant provisions of international treaties, the person will be transferred to judicial organs for criminal prosecution. Until 2006, China has signed the Bilateral Extradition Agreement with 26 countries which includes Thailand and Philippines.

Besides that, China also promulgated some laws contain stipulations relevant to piracy, such as Maritime Traffic Safety Law, 1983, Law on the Territorial Sea and the Contiguous Zone, 1992, and Law on the Exclusive Economic Zone and the Continental Shelf, 1998. The provisions in the above laws on "security", "safety", and "hot pursuit" are relevant, although they are not specifically related to piracy.

2.2 Strengthen marine patrol, surveillance, detection and examination, especially on key sea areas and against major suspected vessels

In China, five main paramilitary forces can be identified with the functions mentioned above. These are the Customs Service, the Maritime Section of the Public Security Bureau, the Maritime Command of the Border 
Security Force, Border Defence and the China Maritime Surveillance (CMS) of the State Oceanic Administration. These five forces have been active in the examination of criminal cases at sea by way of checking suspected vessels and seaman. Whenever any ship is found to be in doubt, investigation will be conducted, and when sufficient evidences are collected, the cases will be handed over to the Public Security Department and the Court for further investigation and settlement in accordance with relevant laws and regulations of China.

\subsection{Active promoting international exchange and cooperation}

Chinese Government has recognized that maritime security is a complex issue that can only be achieved through regional cooperation. In 2002, China and ASEAN have signed Declaration on the Conduct of Parties in the South China Sea (DOC), In 2004, China and ASEAN singed a MOU on Cooperation of Non-traditional Security Issues in 2004. On September $7^{\text {th }}, 2005$, China sent its first delegation to a maritime security conference concerning the Malacca Strait, on which China made a clear position that it supports the coastal states to play the leading role in maintaining the sovereignty and security of the Malacca Strait and China would like to join the cooperation. Indonesian Foreign Minister said "welcome other countries in the region, especially China to help". In July 2006, China and Malaysia signed Sino-Malaysian Maritime Cooperation MOU. On April 27 , 2006, navies of China and Vietnam carried out their first joint patrol in the Gulf of Tonkin, which indicates their cooperation on maintaining order and stability in the South China Sea. On September 4, 2006, China signed the Regional Cooperation Agreement on Anti-Piracy (ReCAPP) which aims to enhance multilateral cooperation among the 10 members of ASEAN plus Japan, India, China, South Korea, Sri Lanka and Bangladesh.

\section{Suggestion}

\subsection{Strengthening jurisdiction and enhance capacity building in legislation and law-enforcement on anti-piracy}

3.1.1 Make clear the definition of piracy in Criminal Law and promulgate and law and legal regulations on piracy.

Although Article 9 of Criminal Law stipulates the jurisdiction on majority of international crime recognized by China, however, China has no definition of piracy in the Criminal Law. The lack of definition and provisions in the Criminal Law, to some extent, affect the anti-piracy efforts. In the event of piracy cases, according to the provisions of Article 232 of the "Criminal Law" and Section 263 provides that the crime of premeditated murder for the robbery sentence. In other words, if these provisions can not be used to impose a monetary penalty, the offenders would have been released. In the trial of "Cheung Son" case, although there were thirteen pirates sentenced to death and nineteen sentenced up to life imprison, there were still six suspects set free for having been found not guilty according to current Criminal Law. The delinquency of current legal system brings a lot of difficulties to the application of anti-piracy. And in fact, the object of the crime, criminal objective and subjective of Robbery in Criminal Law have great different with Piracy in International Criminal Law.

3.1.2 Setting up effective jurisdictional system on Extraditing Maritime Terrorist

Although China has promulgated Extradition Law in 2000 and signed bilateral extradition agreement with 26 countries which includes Thailand and Philippine, however, to the countries which having not signed the bilateral agreement with China, it is very hard to extradite the offenders. In the case of Petro Ranger in 2002, China did not have a bilateral extradition agreement with Malaysia, although the Royal Malaysian Police had requested the Chinese government to extradite the 10 Indonesian criminals to stand trial in Malaysia. At the end, the 10 criminals were repatriated to Indonesia after almost of being 6 months detained. The result of this case caused the misunderstanding of some countries, even some countries criticized Chinese government "Let pirates go free". Therefore, China needs to sign the bilateral extradition agreement with more countries, especially the countries in the South China Sea area, and specially promulgate the provision on extradition of maritime terrorists in the agreement.

3.1.3 Expert group on legal issues. A working group comprising government legal officers, legal staff of the IMO or IMB, legal experts recommended by the shipping community, maritime lawyers, historians studies piracy and academics should be appointed to review the legal issues that arise from the effective connection between domestic law and international law and adjust the new law on piracy timely.

3.2 Building Chinese Coast Guard to strengthening patrol and control in ports, territorial waters and other sea areas under Chinese jurisdiction so as to eliminate any shelter for criminals.

3.2.1 Although the five paramilitary forces play some functions on patrol and surveillance, however, this kind of decentralized maritime managing system does not satisfy the badly need for maintaining safety and good order at sea very well. 
3.2.2 The South China Sea, in particular has become notorious for piracy, and has complex maritime geography with many islands and archipelagos, narrow straits and shipping channels with numerous overlapping claims to maritime jurisdiction, and the risks of tensions and disputes at sea. Moreover, in recent year, some countries criticize the "China Threat". In such situations, navy patrol will increase the tension of this sensitive area. Coast guard may offer advantages over navies for conflicting claims to maritime jurisdiction and political tensions between parties in the South China Sea.

3.2.3 The 1982 UN Convention on the law of the Sea (UNCLOS) led to extended coastal state jurisdiction, particularly through the introduction of the 200-nautical mile exclusive economic zone (EEZ). While coastal states have greater rights in adjacent waters under UNCLOS, they also have increased responsibilities. The ability to undertake the increased tasks is to build a coastguard which has the ability to enforce national maritime laws with wide powers.

3.2.4 Most of the countries in the South China Sea have established coast guard, if China has a coast guard, it will be able to conduct exercise and training with other nations that might not be possible between navies.

All in all, China should combine decentralized five paramilitary forces and build coast guard. Also, it should establish a special anti-piracy team to deal with pirates in South China Sea and establish a team of experts who gather information from dangerous areas, analyze the data and suggest countermeasures.

\subsection{Enhancing cooperation and interaction among States}

Anti-piracy is a complex issue that can only be achieved through regional cooperation.

Strengthen maritime law enforcement cooperation between China and ASEAN countries. Establish channels for China and ASEAN countries to maintain dialogue and contacts between law enforcement agencies at sea; set up an information exchange mechanism, smooth information exchange channels, timely transmit information and intelligence on illegal transnational criminal organizations; jointly deal with maritime security threats; cooperate in active and pragmatic way, timely launch joint exercises and joint handling cases, accumulate experience, improve cooperation efficiency; strengthen maritime law enforcement and step up bilateral and multilateral cooperation in the training of personnel and technical exchanges.

\section{References}

13 Pirates tontenced death. [Online] Available: http://www.geocities.com/TimesSquare/Hangar/4607/00-01/PIR-13-execution.html (December 22, 1999).

China attend the meeting calling for maintaining the security of the Strait of Malacca's safe navigation. (in Chinese) [Online] Available: http://www.gov.cn/zwjw/2005-09/08/content_30156.htm (September 8, 2005).

China letting pirates go free. [Online] Available: http://news.bbc.co.uk/2/hi/asia-pacific/271511.stm (February 3, 1999).

Death sentence for thirteen pirates upheld. [Online] Available: http://english.people.com.cn/english/200001/11/eng20000111Q101.html (January 11, 2000).

$\mathrm{Qu}$ Xuewu. 'China to the Jurisdiction of International Organized Crime and Punishment', (in Chinese). [Online] Available: http://www.iolaw.org.cn/showarticle.asp?id=1261 (November 12, 2006).

Regional Cooperation agreement on anti-piracy. [Online] Available: http://www.observerindia.com/strategic/st060710.htm (July 10, 2006).

Statement by Mr. LIU Zhenmin Head of The Delegation of China At Panel B, The Second Meeting of The United Nations Opened Informal Consultative Process On Oceans and the Law of the Sea. [Online] Available: http://www.china-un.org/eng/zghlhg/flsw/t28537.htm (May 10, 2001).

The international chain piracy, (in Chinese) [Online] Available: http://www.lifeweek.com.cn/2002-09-25/00001645.html (September 25, 2002).

The United Nations press Indonesia. Malaysia and Singapore to maintain the navigational safety of Straits of Malacca. (in Chinese). [Online] Available: http://www.zaobao.com/special/us/pages6/attack050908.html (September 8, 2005).

Zhao, Jianhua. 'The Straits of Malacca and Challenges Ahead: China's Perspective'.

Zou, Keyuan. 'Quelling Sea Piracy in East Asia'. 
Table 1. Total Number of Attacks within Southeast Asia (1994-2005)

\begin{tabular}{|c|c|c|c|c|c|c|c|c|c|c|c|c|}
\hline \multicolumn{13}{|c|}{ Total Number of Attacks within Southeast Asia (1994-2005) } \\
\hline Locations & 1994 & 1995 & 1996 & 1997 & 1998 & 1999 & 2000 & 2001 & 2002 & 2003 & 2004 & 2005 \\
\hline Indonesia & 22 & 33 & 57 & 47 & 60 & 115 & 119 & 91 & 103 & 121 & 94 & 79 \\
\hline Malacca Strait & 3 & 2 & 3 & & 1 & 2 & 75 & 17 & 16 & 28 & 38 & 12 \\
\hline Philippines & 5 & 24 & 39 & 16 & 15 & 6 & 9 & 8 & 10 & 12 & 4 & \\
\hline Singapore Straits & 3 & 2 & 2 & 5 & 1 & 14 & 5 & 7 & 5 & 2 & 8 & 7 \\
\hline Thailand & & 4 & 16 & 17 & 2 & 5 & 8 & 8 & 5 & 2 & 4 & 1 \\
\hline \multicolumn{13}{|l|}{ China/Hongkong/ } \\
\hline Macau & 6 & 31 & 9 & 5 & 2 & & 2 & & & 1 & 3 & 4 \\
\hline HLH area** & 12 & 7 & 4 & 1 & & & & & & & & \\
\hline South China Sea & 6 & 3 & 2 & 6 & 5 & 3 & 9 & 4 & & 2 & 8 & 6 \\
\hline Taiwan & & 2 & & & & & & 2 & 1 & 1 & & \\
\hline Vietnam & 2 & 4 & & 4 & & 2 & 6 & 8 & 12 & 15 & 4 & 10 \\
\hline Total for the year & 59 & 112 & 132 & 101 & 86 & 147 & 233 & 145 & 152 & 184 & 163 & 119 \\
\hline \multicolumn{13}{|c|}{ Source: ICC International Maritime Bureau, Piracy and Armed Robbery Against Ships--Annual Report } \\
\hline \multicolumn{13}{|c|}{ HLH area*: Hong Kong/Luzou/Hainan area } \\
\hline
\end{tabular}

